\title{
The Impact of Covid-19 on Indonesian Muslim Pilgrimage
}

Maharani Alifah Dhiya Rahmadhanitya

Universitas Muhammadiyah Yogyakarta, Yogyakarta, Indonesia maharani.a.isip18@mail.umy.ac.id

Sidik Jatmika

Universitas Muhammadiyah Yogyakarta, Yogyakarta, Indonesia

\section{Article History:}

Received: January 22, 2021

Revised: June 9, 2021

Accepted: June 29, 2021

\begin{abstract}
This article describes the impact of postponement of Umrah and Hajj towards Indonesia during Covid-19 pandemic. The bilateral relations between Saudi Arabia and Indonesia have been going on for a long time. Hajj and Umrah visits are one way to establish bilateral cooperation between Indonesia and Saudi Arabia. During pandemic, Saudi Arabia make a foreign policy to postponement Umrah and Hajj, this policy make Indonesian Muslim unable to pilgrimage Umrah and Hajj. This postponement will impact Indonesia in many sectors. The research method used in this study is a descriptive study and library research aims to understand the reasons for a state to make a foreign policy and understand the impact of these policies towards Indonesia. Islamic Jurisprudence (Figh) concept, Foreign Policy theory, and Foreign Policy Impact Theory are used to analyze the impact of postponement Hajj and Umrah. The findings confirm that the actors that felt the impact were the government, Hajj and Umrah travel agents, and also the Hajj and Umrah pilgrims from Indonesia.
\end{abstract}

Keywords: Covid-19, Hajj, Umrah, Islamic Jurisprudence, Foreign Policy Theory 


\title{
Dampak Covid-19 terhadap Jamaah Haji dan Umrah Indonesia \\ Maharani Alifah Dhiya Rahmadhanitya \\ Universitas Muhammadiyah Yogyakarta, Yogyakarta, Indonesia maharani.a.isip18@mail.umy.ac.id \\ Sidik Jatmika \\ Universitas Muhammadiyah Yogyakarta, Yogyakarta, Indonesia
}

\begin{abstract}
Abstrak
Artikel ini menjelaskan dampak penundaan umrah dan Hajji terhadap Indonesia selama pandemi Covid-19. Hubungan bilateral Arab Saudi dan Indonesia telah berlangsung sejak lama. Kunjungan Hajji dan umrah merupakan salah satu cara menjalin kerjasama bilateral antara Indonesia dan Arab Saudi. Saat terjadi pandemi, Arab Saudi membuat kebijakan luar negeri dengan menunda umrah dan Hajji, kebijakan ini membuat Muslim Indonesia tidak bisa menunaikan ibadah umrah dan Hajji. Penundaan ini akan berdampak pada Indonesia di banyak sektor. Metode penelitian yang digunakan dalam penelitian ini adalah penelitian deskriptif dan studi pustaka ini bertujuan untuk memahami alasan suatu negara membuat kebijakan luar negeri dan memahami dampak kebijakan tersebut terhadap Indonesia. Konsep Fiqih, Teori Kebijakan Luar Negeri, dan Teori Dampak Kebijakan Luar Negeri digunakan untuk menganalisis dampak penundaan Hajji dan umrah. Temuan tersebut menegaskan, aktor yang merasakan dampak adalah pemerintah, biro perjalanan Hajji dan umrah, serta jemaah Hajji dan umrah asal Indonesia.
\end{abstract}

Kata Kunci: Covid-19, Haji, Umrah, Konsep Fiqh, Teori Kebijakan Luar Negeri

\section{INTRODUCTION}

At the beginning of 2020, all countries in the world were shocked by the outbreak of disease caused by the Covid-19 coronavirus. Starting from a local case that occurred in Wuhan, China, to the rapid 
spread that occurred around the world. WHO (World Health Organization) in March 2020, made this outbreak a global pandemic, and asked countries around the world to take immediate action to prevent and overcome the spread of Covid-19 virus. ${ }^{1}$ Actions taken by several countries in the world are lockdown measures. Based on the definition from Cambridge, lockdown can be interpreted as a situation where people are not allowed to enter or leave an area freely because outside was in emergency. ${ }^{2}$

In Italy, initially the government urged residents to stay indoors, and most nightclubs, restaurants, schools, campuses, and cinemas stopped working. However, because cases in Italy continued to increase, the government finally put on a lockdown with tighter supervision and locked several cities. Likewise for Spain, the central government has ordered its citizens to work from home, and business and educational facilities such as schools and colleges have also been closed. ${ }^{3}$ The lockdown policy was also enforced by Saudi Arabia by closing the Riyadh, Makkah, and Medina areas since early March 2020. Prevention measures taken by Saudi Arabia include social distancing, the obligation to wear masks in public places, and work from home. ${ }^{4}$

1 World Health Organization, "WHO Director-General's Opening Remarks at the Media Briefing on COVID-19 - 11 March 2020," March 11, 2020, https://www.who.int/director-general/speeches/detail/who-director-general-sopening-remarks-at-the-media-briefing-on-covid-19---11-march-2020.

2 Posma Sariguna Johnson Kennedy et al., “Analisis Strategi Lockdown atau Pembatasan Sosial dalam Menghambat Penyebaran Covid-19: Sebuah Tinjauan Teoritis," IMAGE: Jurnal Riset Manajemen 9, no. 1 (June 22, 2020): 48-64, https://doi.org/10.17509/image.v9i1.24189.

3 Debora Sanur, “Wacana Kebijakan Lockdown Dalam Menghadapi Covid-19 Di Indonesia," Info Singkat: Kajian Singkat Terhadap Isu Aktual Dan Strategis 12, no. 6 (March 2020): 25-30.

4 Heba M. Adly et al., "Correlation of COVID-19 Pandemic with Healthcare System Response and Prevention Measures in Saudi Arabia," International Journal of Environmental Research and Public Health 17, no. 18 (September 2020): 6666, https://doi.org/10.3390/ijerph17186666. 
Apart from these three cities, restrictions on travel and access in and out were also implemented in 13 other areas in Saudi Arabia. Lockdown was also implemented in two holy places for Muslims, namely the Grand Mosque and the Prophet's Mosque. Until April 2020, the Saudi government took action to continue to close the Grand Mosque and the Prophet's Mosque during Ramadan 1441 AH, making Muslims in various countries and the people of Saudi Arabia unable to pilgrimage Umrah and Hajj. There is a limitation on the number of pilgrims to only 1000 pilgrims from the usual 3.5 million from international and domestic. ${ }^{5}$ This coronavirus pandemic has resulted in people in Saudi Arabia celebrating Eid al-Fitr in a state of lockdown. ${ }^{6}$ Also, this policy makes Indonesian Muslim unable to pilgrimage Umrah and Hajj this year.

During the pandemic, Indonesian Muslims are unable to perform Umrah and Hajj. This postponement will certainly have an impact on various sectors in Indonesia. This study aims to determine the impact that occurs on society and the government in Indonesia, both in the economic field and the psychological impact felt by Indonesian Muslim who are unable to pilgrimage Umrah and Hajj this year. In addition, the author also wants to analyse the reasons Saudi Arabia postponed the Hajj and Umrah and bilateral relations between two countries regarding Hajj and Umrah during a pandemic. This lockdown policy prevents many Muslim countries from carrying out the Hajj and Umrah pilgrimages. This evokes the question, how did the postponement of Hajj and Umrah impact Indonesia?

5 Shahul H. Ebrahim et al., "The Hajj Pilgrimage during the COVID-19 Pandemic in 2020: Event Hosting without the Mass Gathering," Journal of Travel Medicine 28, no. 2 (March 2021): taaa194, https://doi.org/10.1093/jtm/taaa194.

$\begin{array}{cccc} & 6 \text { Rosmha Widiyani, "Sejumlah Kebijakan Arab Saudi Hingga Akhirnya } \\ \text { Izinkan } & \text { Haji } 2020 & \text { Terbatas," } & \text { detiknews, June 23, }\end{array}$ https:/ / news.detik.com/berita/d-5064978/ sejumlah-kebijakan-arab-saudi-hinggaakhirnya-izinkan-haji-2020-terbatas. 


\section{METHOD}

In this study, the authors used a qualitative analysis and the interview method, in which the authors tried to explain the issues discussed. While the type of data used is secondary data, the author uses data derived from documents, books, journals, articles, and news from the Internet, and other sources, which are considered relevant to the problems in this study. The data study technique used in this research is library research, namely by collecting data and information from the literature related to the issues discussed.

\section{RESULTS}

\section{Saudi Arabia Foreign Policy towards Hajj and Umrah}

There are three factors that influence Saudi Arabia to make foreign policy, the first factor is we can see on the Saudi Arabia's domestic politics. The condition that is happening in Saudi Arabia, there are increased positive cases of Covid-19. This is because the lockdown was relaxed in May 2020. Saudi Arabia experienced an increase in the number of daily infections and deaths. ${ }^{7}$ As of November 29, 2020, the number of Covid-19 cases in Saudi Arabia has reached 357,126. ${ }^{8}$ This domestic political factor makes Saudi Arabia postpone Hajj and Umrah.

The second factor that influences Saudi Arabia for making the foreign policy is the international context. Currently, the problem that countries and international actors are trying to solve is the Covid-19

7 Ahmad Naufal Dzulfaroh, “Arab Saudi Pertimbangkan Pembatalan Haji, Pertama dalam Sejarah Modern," KOMPAS.com, June 13, 2020, https:/ / www.kompas.com/tren/read/2020/06/13/143100165/arab-saudipertimbangkan-pembatalan-haji-pertama-dalam-sejarah-modern.

8 Laith N. Al-Eitan et al., "Bat-Borne Coronaviruses in Jordan and Saudi Arabia: A Threat to Public Health?," Viruses-Basel 12, no. 12 (December 2020): 1413, https://doi.org/10.3390/v12121413. 
pandemic problem. In addition, the policy to postpone the Hajj and Umrah pilgrimage is influenced by the WHO organization. WHO Regional Head for the East Mediterranean, Dr Dalia Samhouri, said that decisions regarding annual religious activities in the world should be made under WHO supervision, and advised Saudi Arabia to postpone such activities. ${ }^{9}$

And the last factor is the economic condition in Saudi Arabia. Saudi Arabia is a country that has the largest economy in the Arab world and the Middle East. Saudi Arabia's source of income comes from petroleum and is the world's largest oil exporter. In addition, other sources come from the tourism sector. Even though during the pandemic Saudi Arabia experienced a decline in income in the petroleum and tourism sectors, the economy of Saudi Arabia continued to survive well. This was supported by the Saudi Vision 2030 program, the program created to reduce dependence on petroleum.

In addition, Saudi Arabia also launched the National Transformation Program to create a private sector-driven economy and job opportunities for the Saudi Arabian workforce. The program allows foreign investors and multinational companies to easily enter the Saudi Arabian market. ${ }^{10}$ These factors make Saudi Arabia make a policy of postponement of Umrah and Hajj activity for all pilgrims.

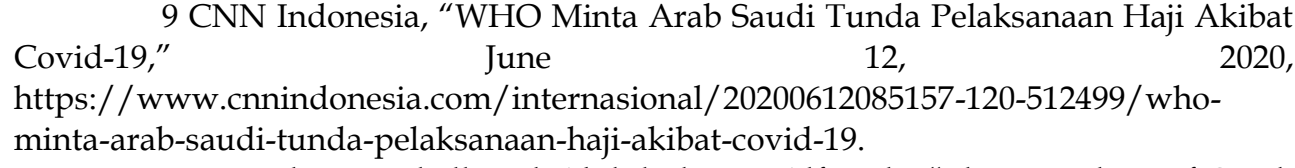

10 Brendan Mitchell and Abdulrahman Alfuraih, "The Kingdom of Saudi Arabia: Achieving the Aspirations of the National Transformation Program 2020 and Saudi Vision 2030 Through Education," Journal of Education and Development 2, no. 3 (September 20, 2018): 36, https://doi.org/10.20849/jed.v2i3.526; Abdullah Addas, "Enhanced Public Open Spaces Planning in Saudi Arabia to Meet National Transformation Program Goals," Current Urban Studies 08, no. 02 (April 29, 2020): 184, https://doi.org/10.4236/cus.2020.82010; Muhammad Babar Khan and Sadia Iqbal, 


\section{The Impact of Postponement Towards Indonesia}

The foreign policy made by Saudi Arabia by postponement of Hajj and umrah will certainly impact many actors in Indonesia. The policies made by Saudi Arabia had an impact on Indonesia, both positive and negative impact. The actors that felt the impact were the government, Hajj and Umrah travel agents, and the Hajj and Umrah pilgrims from Indonesia. The impacts felt by those actors such as economic impact and the psychological impact.

\section{Government of Indonesia}

The Indonesian government as an actor who plays a role in making it easier for Indonesian Muslims to carry out the Hajj and Umrah pilgrimage. So that the Indonesian government has a very important role on the implementation of the Hajj and Umrah pilgrimages can be carried out. The Indonesian government gets quite a lot of profit from the implementation of Hajj and Umrah. The umrah industry had the potential to generate state revenue of up to $\operatorname{Rp} 7.2$ trillion per year, even two to three times as much.

The increase in National GDP is based on three components, namely worship guide, manasik Umrah, and travel profits. The total state revenue if per person, pays for the three components, it is Rp 2.275 million. If this is multiplied by the 636 thousand pilgrims each year, the profit the state get is around Rp1.4 trillion. ${ }^{11}$ The government can find it difficult to get income and income tax (PPh) and value added tax (PPn) from the Umrah and Hajj industry in Indonesia. So

\footnotetext{
"Vision 2030 and the National Transformation Program," in Research, Innovation and Entrepreneurship in Saudi Arabia (Routledge, 2020), 146-66.

11 Aqwam Fiazmi Hanifan, "Komersialisasi Umrah, Ketika Ibadah Bernilai Bisnis," tirto.id, August 31, 2016, https:/ / tirto.id/komersialisasi-umrah-ketika-ibadahbernilai-bisnis-Dl.
} 
that the postponement of the Hajj and Umrah pilgrimages due to the Covid-19 pandemic will have an impact on Indonesian economy.

\section{Hajj and Umrah Travel Agents}

Other actors affected by the postponement of the Hajj and Umrah pilgrimages are the Umrah and Hajj travel agencies. The Hajj and Umrah Travel Agency is a travel agency that arranges and dispatches Hajj and Umrah pilgrims from Indonesia. The travel companies will lose potential revenue of around $\mathrm{Rp} 22.5$ trillion in 2020 if there are 1 million Umrah pilgrims and 17,500 pilgrims.

The postponement of the Hajj and Umrah pilgrimage has resulted in travel agencies not earning income, but they still must pay rent, electricity, internet, taxes, and employee salaries. This makes travel agencies go bankrupt because they only survive on the savings they have. Currently, several travel companies have even started to carry out employee housing and layoffs. Losses were also experienced by one of the Hajj and Umrah finance companies, AMITRA, a subsidiary of Astra International. AMITRA is a company that collaborates with 300 Hajj and Umrah Travel Agencies in Indonesia. Now, they must stop operating, even their employees must be laid off, because for the past three months there has been no activity and no income to the company. ${ }^{12}$

The Umrah and Hajj travel agencies will also suffer losses if pilgrims who have arrived in Saudi Arabia are positive for Covid-19. This is because pilgrims affected by the Covid-19 virus must carry out isolation until they recover, and the funds used for this isolation use

12 Bisnis News, "Penundaan Pengiriman Haji dan Umrah Serta Dampaknya Ke Sektor Usaha Terkait," BISNISNEWS.id, June 3, 2020, https:/ / bisnisnews.id/detail/berita/penundaan-pengiriman-haji-dan-umrah-sertadampaknya-ke-sektor-usaha-terkait. 
health insurance. ${ }^{13}$ Even though the pilgrims have already paid for the health insurance, if the pilgrims are still not healed, the costs will be borne by the Hajj and Umrah travel agents.

\section{Indonesia Muslim Pilgrims}

Indonesia Hajj and Umrah pilgrims are the most disadvantaged actors in this postponement of Hajj and Umrah. This is because pilgrims from Indonesia have paid for various facilities, such as plane tickets, visas, hotels, and other facilities. If the Hajj and Umrah pilgrims want to make a refund, then only get a refund of up to 90 percent of the Umrah fee. ${ }^{14}$ In addition, Hajj and Umrah pilgrims who will depart during this pandemic will experience increases in travel costs, lodging, transportation, swab test fees, and guide fees. ${ }^{15}$ This is a disadvantage for the pilgrims and Umrah pilgrims because they have been waiting a long time for departure, and have to pay additional money when leaving.

The psychological impact felt by the Hajj and Umrah pilgrims because of postponement of the Hajj and Umrah pilgrimages, they felt sad and disappointed because they have already made preparations for departure, have made payments and so on. ${ }^{16}$ Apart from that, the

\footnotetext{
13 Nicholas Ryan Aditya, "Biaya Karantina Jemaah Umrah Yang Terpapar Covid-19 Ditanggung Asuransi," KOMPAS.com, November 6, 2020, https:/ / nasional.kompas.com/read/2020/11/06/22581321/biaya-karantina-jemaahumrah-yang-terpapar-covid-19-ditanggung-asuransi.

14 Bangun Santoso and Achmad Fauzi, "Diminta Jadwal Ulang, Refund Jemaah Umrah Tak Dapat Dana 100 Persen," suara.com, March 8, 2020, https:/ / www.suara.com/news/2020/03/08/120312/diminta-jadwal-ulang-refundjemaah-umrah-tak-dapat-dana-100-persen.

15 Nabilla Ramadhian, "Biaya Umrah Saat Pandemi Naik, Harga Terendah Rp 26 Juta," KOMPAS.com, November 2020, https:/ /travel.kompas.com/read/2020/11/05/191900427/biaya-umrah-saat-pandeminaik-harga-terendah-rp-26-juta.

16 Datuk Haris Molana, “Jemaah Sumut Kecewa Saudi Setop Umrah, Ada yang Sudah Ditepungtawari," detiknews, February 27, 2020,
} 
pilgrims also felt disappointment, this was because many Indonesian pilgrims who had waited for more than five years to be able to carry out the pilgrimage had to be delayed and had to wait until next year. With the postponement of the Hajj and Umrah pilgrimages, the queues for Hajj will be even longer, due to the Saudi Arabia policy regarding limiting the age of prospective pilgrims and the tightening of health procedures and requirements for the departure of Hajj and Umrah pilgrims.

Indonesia not only felt the negative impact of the Saudi Arabian policy but in fact, there is a positive impact that can be obtained. The positive impact of postponing Umrah and Hajj is that it can reduce the spread of positive cases that have occurred in Indonesia and supports the efforts of WHO to immediately end this Covid-19 pandemic by not sending pilgrims to carry out Umrah and Hajj. The Indonesian government can focus more on monitoring the covid-19 virus in all parts of Indonesia, such as by optimizing regional restrictions and vaccination for the community. By continuing to send pilgrims for Umrah and Hajj, it is feared that the pilgrims will be exposed to the virus on the way, and later it will have an impact on causing a new Covid-19 cluster.

\section{Recent Development on Saudi Arabia Policy towards Umrah}

The bilateral relations carried out by Saudi Arabia and Indonesia, especially on Hajj and Umrah activities, are based on the Islamic jurisprudence concept. This is because these two countries are the Dar al-Islam and the Darus-Suluh countries, so that cooperation between the two countries is prioritized. On November 1, 2020, Saudi Arabia issued a policy to reopen Umrah for the international community. In this case, it is due to the very close relationship

\footnotetext{
https:/ / news.detik.com/berita/d-4917022/jemaah-sumut-kecewa-saudi-setop-umrahada-yang-sudah-ditepungtawari.
} 
between Saudi Arabia and Indonesia, besides this Hajj and Umrah activities are very beneficial for both countries, so that Saudi Arabia allows Indonesia to send Umrah pilgrims.

Saudi Arabia makes policy by limiting the age of prospective pilgrims who will carry out the Umrah pilgrimage as well as tightening health procedures and requirements for the departure of Umrah pilgrims. Pilgrims who are allowed to carry out the Umrah pilgrimage are those aged 18 to 50 years. Another requirement is that the pilgrims must not have comorbid diseases and before departure must take a PCR or swab test. ${ }^{17}$ Umrah pilgrims also need to be quarantined for three days at the hotel where they are staying and are prohibited from leaving the hotel. Apart from that, Saudi Arabia has also made a policy on limiting the Umrah quota. ${ }^{18}$

On November 16, 2020, the government of Saudi Arabia do postponement again the Umrah pilgrimages for Indonesian Muslim. This was done because of the Umrah pilgrims from Indonesia infected with the Covid-19 virus ${ }^{19}$ and positive cases of Covid-19 in Indonesia continue to experience a significant increase. By making a policy of postponement against Umrah activity for Indonesian pilgrims, Saudi Arabia wants to protect the people of Saudi Arabia so that there would be no increase in positive cases of Covid-19.

17 Hashim Talib Hashim et al., "The Hajj and COVID-19: How the Pandemic Shaped the World's Largest Religious Gathering," American Journal of Tropical Medicine and Hygiene 104, no. 3 (March 2021): 797-99, https:/ / doi.org/10.4269/ajtmh.20-1563.

18 Abdul Malik, "Ini Ketentuan Kemenag Soal 9 Pedoman Penyelenggaran Umroh di Masa Pandemi," Bareksa.com, November 3, 2020, https://www.bareksa.com/berita/umroh/2020-11-03/ini-ketentuan-kemenag-soal-9pedoman-penyelenggaran-umroh-di-masa-pandemi.

19 Dezy Rosalia Piri, "Saudi Arabia Temporarily Suspends Umrah Visas on Indonesian Pilgrims Due to Covid-19 Cases," KOMPAS.com, November 16, 2020, https:/ / go.kompas.com/read/2020/11/16/195101074/saudi-arabia-temporarilysuspends-umrah-visas-on-indonesian-pilgrims-due-to-covid. 


\section{Pilgrims Before and during the Covid-19 Pandemic}

There are differences in policies carried out by Saudi Arabia on the implementation of Hajj and Umrah for Muslim pilgrims which were carried out before and during the Covid-19 pandemic. The new policy was made by Saudi Arabia to overcome and stop the spread of the Covid-19 virus. Before this pandemic, Hajj and Umrah were allowed to be carried out by all Muslims in the world without any restrictions on the age or number of the pilgrims. Muslim pilgrims also don't need to do quarantine, PCR tests, and any complicated medical tests. In addition, the costs that should be paid by the pilgrims are not too expensive for regular Umrah costs around IDR 23 million to IDR 30 million. Before the pandemic, Indonesia can send Umrah pilgrims around 900 million to 1.5 million and Hajj pilgrims around 2.4 million.

The Saudi Arabia government's policy regarding Umrah, and Hajj has changed during this pandemic. Currently, pilgrims who will do the Umrah and Hajj are limited only for those who are 18 to 50 years old. Before departure, pilgrims are obliged to take a PCR test three times, and when they arrive in Saudi Arabia, pilgrims must quarantine for three days at the hotel. Umrah activities are only carried out once with a maximum time of three hours, prayer activities carried out individually, and there are only guides who come from Saudi Arabia. Another change is that pilgrims who want to carry out Hajj and Umrah must pay more than normal fees for PCR tests and other accommodations during the quarantine activity. This makes Indonesia only send 216.560 pilgrims for Umrah activities and there has been no departure of Hajj pilgrims since the 2020 and 2021 pandemics

The following table shows comparisons of procedures and the number of pilgrims for Hajj and umrah, before and during Covid-19 pandemic. 
Table 1. Comparison of procedures and the number of pilgrims

\begin{tabular}{|c|c|c|}
\hline NO & $\begin{array}{l}\text { Before the Covid-19 } \\
\text { Pandemic }\end{array}$ & During the Covid-19 Pandemic \\
\hline 1 & Pilgrims are not limited by age & $\begin{array}{l}\text { The age of the pilgrims } \\
\text { are limited (18-50 years) }\end{array}$ \\
\hline 2 & There are no PCR test & Pilgrims must do the PCR test three times \\
\hline 3 & $\begin{array}{c}\text { Pilgrims do not need to do } \\
\text { any complicated medical tests }\end{array}$ & $\begin{array}{c}\text { Pilgrims are obliged to fill out } \\
\text { two documents regarding the health statement } \\
\text { and health protocol }\end{array}$ \\
\hline 4 & $\begin{array}{c}\text { There is no spraying of } \\
\text { disinfectant }\end{array}$ & $\begin{array}{l}\text { The pilgrims luggage were } \\
\text { sprayed with disinfectant }\end{array}$ \\
\hline 5 & $\begin{array}{l}\text { Bus can accommodate } \\
48-50 \text { pilgrims }\end{array}$ & Bus only accommodate $20-22$ pilgrims \\
\hline 6 & There is no quarantine policy & $\begin{array}{l}\text { Pilgrims must do quarantine } \\
\text { at the hotel for three days }\end{array}$ \\
\hline 7 & $\begin{array}{l}\text { There is no time limit } \\
\text { for Umrah activities }\end{array}$ & $\begin{array}{l}\text { Umrah activities are only carried out once } \\
\text { with a maximum time of three hours }\end{array}$ \\
\hline 8 & $\begin{array}{l}\text { Prayer activities are } \\
\text { carried out together }\end{array}$ & Prayer activities carried out individually \\
\hline 9 & $\begin{array}{l}\text { Guides come from various } \\
\text { countries }\end{array}$ & There are only guides from Saudi Arabia \\
\hline 10 & $\begin{array}{l}\text { Regular Umrah costs around } \\
\text { IDR } 23 \text { million to IDR } 30 \\
\text { million }\end{array}$ & $\begin{array}{l}\text { Umrah costs have increased, } \\
\text { around IDR } 32 \text { million to IDR } 35 \text { million }\end{array}$ \\
\hline 11 & $\begin{array}{l}\text { The number of Umrah } \\
\text { pilgrims from Indonesia are } \\
\text { around } \\
900 \text { million to } 1.5 \text { million }\end{array}$ & $\begin{array}{c}\text { Indonesia sent } 529 \text { groups with total } 216.560 \\
\text { pilgrims } \\
\text { for Umrah activities }\end{array}$ \\
\hline
\end{tabular}




\begin{tabular}{|c|c|c|}
\hline 12 & $\begin{array}{c}\text { Hajj activities have } \\
\text { no restrictions on pilgrims }\end{array}$ & $\begin{array}{c}\text { Hajj activities are only carried out } \\
\text { by } 1.000 \text { pilgrims who } \\
\text { have been strictly selected }\end{array}$ \\
\hline 13 & $\begin{array}{c}\text { In 2019, Indonesia Hajj } \\
\text { pilgrims } \\
\text { are around } 2.4 \text { million }\end{array}$ & $\begin{array}{c}\text { No departure of Haj pilgrims since the } 2020 \\
\text { and 2021 pandemics }\end{array}$ \\
\hline
\end{tabular}

In 2021, the Indonesian government cancelled the delivery of hajj, it was due to the policies of the Saudi Arabian government and the Indonesian government. The government of Saudi Arabia makes that policy because of the health, safety, and security of the pilgrims who are threatened due to the COVID-19 pandemic that has hit the world. So that the Saudi Arabian government only carries out Hajj with a limited quota, especially for Saudi Arabian countries and expatriates living in Saudi Arabia. It resulted in the Indonesian government not being able to send pilgrims to Saudi Arabia. ${ }^{20}$ The General Directorate of Hajj and Umrah Organization in Indonesia said that for the implementation of Umrah activities, there was opening and closing of the Saudi Arabian airport and the implementation of health protocols during the flight. Until then, there was a spike in Covid-19 globally, so for safety and security, Saudi Arabia then imposed a lockdown. In addition, there are no departures for Hajj activities for Indonesian pilgrims during the COVID-19 pandemic. For regular flights to Saudi Arabia, such as business trips, tourism activities, or other interests, Indonesia has not yet received a permit to carry out these flights. ${ }^{21}$

20 Gempita Surya, “Fakta Pembatalan Haji 2021, Dari Alasan Hingga Prioritas Keberangkatan Tahun 2022," KOMPAS.com, June 6, 2021, https:/ / www.kompas.tv/article/180931/fakta-pembatalan-haji-2021-dari-alasanhingga-prioritas-keberangkatan-tahun-2022.

21 Adhyasta Dirgantara, "Dubes Saudi: 11 Negara Diizinkan Masuk Tak Terkait Haji dan Umroh," detiknews, June 3, 2021, https://news.detik.com/berita/d5592610/dubes-saudi-11-negara-diizinkan-masuk-tak-terkait-haji-dan-umroh. 


\section{DISCUSSION}

This study shows that Saudi Arabia's policy to postpone Hajj and Umrah activities for all Muslims in the world, including Indonesia, certainly has an impact on actors that contribute with these activities. There are positive and negative impacts because of this policy. The Indonesian government, Hajj and umrah travel agents, and Indonesian pilgrims, are the actors who get the impact from this policy. The negative impact felt by these actors is economic and psychological. The economic impact, such as decreased income for the state, then for Hajj and Umrah travel agents, this postponement resulted in them being unable to pay employee salaries and other necessities so that most of them went bankrupt. For the pilgrims, they experience economic losses because they are required to add additional costs if they want to carry out Hajj and Umrah. Apart from the economy, the pilgrims also feel psychological impacts such as feeling disappointed because they must experience delays in departures.

The impact felt from the postponement of Hajj and Umrah is not only negative but also the positive impact that can be taken by Indonesia. With this postponement, the Indonesian government can focus more on overcoming the problem of the spread of the Covid-19 virus in the country. In addition, it is feared that if Indonesia continues to send Umrah and Hajj pilgrims to Saudi Arabia, it will increase the opportunity for a new covid-19 cluster in Indonesia, because pilgrims may catch the virus on their way. With this postponement, it is hoped that it will immediately end the Covid-19 virus pandemic worldwide. Even so, Saudi Arabia also continues to open Hajj and Umrah with very strict requirements, this is done to overcome the spread of the Covid-19 virus in Saudi Arabia. These requirements include an increase in the costs of Umrah and Hajj, restrictions on the age of 
pilgrims and strict health requirements, such as quarantine and swab tests. ${ }^{22}$

This study is different from previous studies on the same topic, namely Pilgrimage and Covid-19. In previous studies, many researchers only explained in general about the covid-19 and did not mention specifically the country that was researched. In addition, there is also research that only explains in general terms the impact of Covid-19 on travel to religious destinations. Other research also explains the Islamic laws related to the cancellation of the Hajj during this pandemic. So that in this study there is a renewal which lies in the focus of this research, namely on the impact of the Saudi Arabian government policy regarding the postponement in carrying out Hajj and Umrah during the pandemic. This study focuses on the positive and negative impacts felt by actors in Indonesia who are involved in the implementation of Hajj and Umrah.

\section{CONCLUSION}

The policy of postponement of Hajj and Umrah that Saudi Arabia made were influenced by several factors, domestic politics, international context, and economic conditions. The postponement of the Hajj and Umrah pilgrimages certainly has an impact on both countries. For Indonesia, the impact is felt not only by one actor, but there are several actors who also feel the impact of this policy, namely the Indonesian government, Hajj and Umrah travel agents, and the Hajj and Umrah pilgrims from Indonesia. The Indonesian government and Hajj and Umrah travel agents received the impact of the economic loss, while the Hajj and Umrah pilgrims from Indonesia felt the impact on the economy and psychological impact. While the positive impact

22 Anas Khan et al., "Estimating the COVID-19 Risk during the Hajj Pilgrimage," Journal of Travel Medicine 27, no. 8 (December 2020): taaa157, https://doi.org/10.1093/jtm/taaa157. 
of this policy, Indonesia is not worried about a new covid-19 cluster in the country and is one of the efforts to be able to immediately end this Covid-19 pandemic.

Postponing Umrah and Hajj activities during the Covid-19 pandemic is the right decision. Although the impact of this policy felt by many actors that relate with these activities and also the impact obtained not only on one sector, but the policies also carried out by the Saudi Arabian government are actions that need to be supported by all actors. That is because with this postponement the spread of the Covid-19 virus can be avoided and can save the lives of many people. It is hoped that the Indonesian government will not be too imposing to continue carrying out Hajj and Umrah activities during this pandemic, it would be better if the government and the Indonesian people could focus more on overcoming the spread of this virus domestically.

The case of the Covid-19 pandemic is an aspect that supports the process in this research. The author hopes that with this research, readers can find out the positive and negative impacts that Indonesia has on the Saudi Arabian government policy to postpone the Hajj and Umrah pilgrimage activities. This policy does not only have an impact on one actor but there are also several actors related to this activity who are also affected. In addition, because the topic of pilgrimage in the Covid-19 pandemic is still very rarely discussed, the author wants readers to know the latest information regarding the state of Hajj and Umrah activities during the Covid-19 pandemic. Although in practice the policy regarding pilgrimage during the Covid-19 pandemic has been implemented, the authors hope that the study that discusses this topic must be improved again. 


\section{REFERENCES}

Addas, Abdullah. "Enhanced Public Open Spaces Planning in Saudi Arabia to Meet National Transformation Program Goals." Current Urban Studies 08, no. 02 (April 29, 2020): 184. https:// doi.org/10.4236/cus.2020.82010.

Aditya, Nicholas Ryan. "Biaya Karantina Jemaah Umrah Yang Terpapar Covid-19 Ditanggung Asuransi." KOMPAS.com, November 6 , 2020. https:// nasional.kompas.com/read/2020/11/06/22581321/b iaya-karantina-jemaah-umrah-yang-terpapar-covid-19ditanggung-asuransi.

Adly, Heba M., Imad A. AlJahdali, Mohammed A. Garout, Abdullah A. Khafagy, Abdulla A. Saati, and Saleh A. K. Saleh. "Correlation of COVID-19 Pandemic with Healthcare System Response and Prevention Measures in Saudi Arabia." International Journal of Environmental Research and Public Health 17, no. 18 (September 2020): 6666. https:// doi.org/10.3390/ijerph17186666.

Al-Eitan, Laith N., Amneh H. Tarkhan, Mansour A. Alghamdi, Denise A. Marston, Guanghui Wu, Lorraine M. McElhinney, Ian H. Brown, and Anthony R. Fooks. "Bat-Borne Coronaviruses in Jordan and Saudi Arabia: A Threat to Public Health?" VirusesBasel 12, no. 12 (December 2020): 1413. https:/ / doi.org/10.3390/v12121413.

Bisnis News. "Penundaan Pengiriman Haji dan Umrah Serta Dampaknya Ke Sektor Usaha Terkait." BISNISNEWS.id, June 3, 2020. https://bisnisnews.id/detail/berita/penundaanpengiriman-haji-dan-umrah-serta-dampaknya-ke-sektorusaha-terkait.

CNN Indonesia. "WHO Minta Arab Saudi Tunda Pelaksanaan Haji Akibat Covid-19," June 12, 2020. https://www.cnnindonesia.com/internasional/202006120851 
57-120-512499/who-minta-arab-saudi-tunda-pelaksanaanhaji-akibat-covid-19.

Dirgantara, Adhyasta. “Dubes Saudi: 11 Negara Diizinkan Masuk Tak Terkait Haji dan Umroh." detiknews, June 3, 2021. https:// news.detik.com/berita/d-5592610/dubes-saudi-11negara-diizinkan-masuk-tak-terkait-haji-dan-umroh.

Dzulfaroh, Ahmad Naufal. “Arab Saudi Pertimbangkan Pembatalan Haji, Pertama dalam Sejarah Modern.” KOMPAS.com, June 13, 2020.

https:// www.kompas.com/tren/read/2020/06/13/14310016

5/arab-saudi-pertimbangkan-pembatalan-haji-pertamadalam-sejarah-modern.

Ebrahim, Shahul H., Yusuf Ahmed, Saleh A. Alqahtani, and Ziad A. Memish. "The Hajj Pilgrimage during the COVID-19 Pandemic in 2020: Event Hosting without the Mass Gathering." Journal of Travel Medicine 28, no. 2 (March 2021): taaa194. https:// doi.org/10.1093/jtm/taaa194.

Hanifan, Aqwam Fiazmi. "Komersialisasi Umrah, Ketika Ibadah Bernilai Bisnis." tirto.id, August 31, 2016. https:/ / tirto.id/komersialisasi-umrah-ketika-ibadah-bernilaibisnis-Dl.

Hashim, Hashim Talib, Maryam Salma Babar, Mohammad Yasir Essar, Mustafa Ahmed Ramadhan, and Shoaib Ahmad. "The Hajj and COVID-19: How the Pandemic Shaped the World's Largest Religious Gathering." American Journal of Tropical Medicine and Hygiene 104, no. 3 (March 2021): 797-99. https:// doi.org/10.4269/ajtmh.20-1563.

Kennedy, Posma Sariguna Johnson, Timothy Wisnu Harya P, Emma Tampubolon, and Muhammad Fakhriansyah. "Analisis Strategi Lockdown atau Pembatasan Sosial dalam Menghambat Penyebaran Covid-19: Sebuah Tinjauan Teoritis." IMAGE : Jurnal Riset Manajemen 9, no. 1 (June 22, 2020): 48-64. https://doi.org/10.17509/image.v9i1.24189. 
Khan, Anas, Kingsley Lezor Bieh, Ahmed El-Ganainy, Sujoud Ghallab, Abdullah Assiri, and Hani Jokhdar. "Estimating the COVID-19 Risk during the Hajj Pilgrimage." Journal of Travel Medicine 27, no. 8 (December 2020): taaa157. https:// doi.org/10.1093/jtm/taaa157.

Khan, Muhammad Babar, and Sadia Iqbal. "Vision 2030 and the National Transformation Program." In Research, Innovation and Entrepreneurship in Saudi Arabia, 146-66. Routledge, 2020.

Malik, Abdul. "Ini Ketentuan Kemenag Soal 9 Pedoman Penyelenggaran Umroh di Masa Pandemi." Bareksa.com, November 3 , 2020. https:/ / www.bareksa.com/berita/umroh/2020-11-03/iniketentuan-kemenag-soal-9-pedoman-penyelenggaran-umrohdi-masa-pandemi.

Mitchell, Brendan, and Abdulrahman Alfuraih. "The Kingdom of Saudi Arabia: Achieving the Aspirations of the National Transformation Program 2020 and Saudi Vision 2030 Through Education." Journal of Education and Development 2, no. 3 (September 20 , 2018): 36. https:// doi.org/10.20849/jed.v2i3.526.

Molana, Datuk Haris. "Jemaah Sumut Kecewa Saudi Setop Umrah, Ada yang Sudah Ditepungtawari." detiknews, February 27, 2020. https://news.detik.com/berita/d-4917022/jemaahsumut-kecewa-saudi-setop-umrah-ada-yang-sudahditepungtawari.

Nabilla Ramadhian. "Biaya Umrah Saat Pandemi Naik, Harga Terendah Rp 26 Juta." KOMPAS.com, November 5, 2020. https:/ / travel.kompas.com/read/2020/11/05/191900427/bia ya-umrah-saat-pandemi-naik-harga-terendah-rp-26-juta.

Piri, Dezy Rosalia. "Saudi Arabia Temporarily Suspends Umrah Visas on Indonesian Pilgrims Due to Covid-19 Cases." KOMPAS.com, November 16, 2020. https://go.kompas.com/read/2020/11/16/195101074/saudi- 
arabia-temporarily-suspends-umrah-visas-on-indonesianpilgrims-due-to-covid.

Santoso, Bangun, and Achmad Fauzi. "Diminta Jadwal Ulang, Refund Jemaah Umrah Tak Dapat Dana 100 Persen." suara.com, March 8 , 2020. https://www.suara.com/news/2020/03/08/120312/diminta -jadwal-ulang-refund-jemaah-umrah-tak-dapat-dana-100persen.

Sanur, Debora. “Wacana Kebijakan Lockdown Dalam Menghadapi Covid-19 Di Indonesia." Info Singkat: Kajian Singkat Terhadap Isu Aktual Dan Strategis 12, no. 6 (March 2020): 25-30.

Surya, Gempita. “Fakta Pembatalan Haji 2021, Dari Alasan Hingga Prioritas Keberangkatan Tahun 2022." KOMPAS.com, June 6, 2021. https://www.kompas.tv/article/180931/faktapembatalan-haji-2021-dari-alasan-hingga-prioritaskeberangkatan-tahun-2022.

Widiyani, Rosmha. "Sejumlah Kebijakan Arab Saudi Hingga Akhirnya Izinkan Haji 2020 Terbatas." detiknews, June 23, 2020. https://news.detik.com/berita/d-5064978/sejumlahkebijakan-arab-saudi-hingga-akhirnya-izinkan-haji-2020terbatas.

World Health Organization. "WHO Director-General's Opening Remarks at the Media Briefing on COVID-19 - 11 March 2020," March 11, 2020. https://www.who.int/directorgeneral/speeches/detail/who-director-general-s-openingremarks-at-the-media-briefing-on-covid-19---11-march-2020. 
Maharani Alifah Dhiya Rahmadhanitya \& Sidik Jatmika

22 | Millah Vol. 21, No. 1 Agustus 2021 